\title{
Response of Egyptian Cotton to Soil and Foliar Potassium Application Under Calcareous Soil Conditions
}

\author{
Gomaa, M.A. ${ }^{1}$, Radwan, F.I. ${ }^{1}$, Ibrahim, I.A.E. ${ }^{1}$, Emara, M.A. ${ }^{2}$ and Kattosh, \\ A.A. ${ }^{2}$ \\ Plant Production Dept., Fac. of Agric., (Saba Basha), Alexandria Univ., Alexandria, \\ Egypt.
}

Agronomy Dept., Cotton Res. Inst., Agric. Res. Center, Giza, Egypt

Emara, M.A. e-mail: mostafacotton@yahoo.com, Kattosh, A.A.email:a.kattosh@yahoo.com

\begin{abstract}
Two field trials were conducted in a highly calcareous sandy clay loam soil at Nubaria Agric. Res. Station, Agric. Res. Center, Alexandria governorate, Egypt during 2012 and 2013 seasons to study the effect of some sources of potassium fertilizer, soil and foliar potassium application treatments on growth, earliness, yield and its components of Egyptian long staple cotton cultivar Giza 86 (Gossypium barbadense, L.). Potassium fertilizer was added according to the experimental treatments (source, rate, method and date of application). Potassium sulphate $\left(48 \% \mathrm{~K}_{2} \mathrm{O}\right)$ was applied at the rate of 24 and $2.4 \mathrm{~kg} \mathrm{~K} \mathrm{~K}_{2} \mathrm{O} / \mathrm{fed}$., for the soil and foliar applications, respectively. Potassium humate fertilizer $\left(20 \%\right.$ humic acid and $\left.8 \% \mathrm{~K}_{2} \mathrm{O}\right)$ was applied at the rate of 2 and 1 L/fed., for the soil and foliar applications, respectively. Potassein fertilizer $\left(30 \% \mathrm{~K}_{2} \mathrm{O}\right.$ and $\left.10 \% \mathrm{P}_{2} \mathrm{O}_{5}\right)$ was applied at the rate of 2 and $1 \mathrm{~L} / \mathrm{fed}$., for the soil and foliar applications, respectively. The soil applications after thinning in the form of potassium source. The experimental design was a split plot with four replications. The main plots involved the three sources of potassium fertilizer namely; A- Potassium sulphates, BPotassium humate and C- Potassein. The sub main plots involved the five treatments of potassium application namely; 1- Soil application at thinning, 2- Soil application + foliar spraying two times (at initiation of flowering and two weeks after flowering), 3- Soil application + foliar spraying three time (at squaring, initiation of flowering and two weeks after flowering), 4- Foliar spraying two times ( at initiation of flowering and two weeks after flowering) and 5- Foliar spraying three times (at squaring, initiation of flowering and two weeks after flowering). The most important results obtained could be summarized as follows:

1) The all sources of potassium had significant effects on all growth attributes in 2012 and 2013 seasons.

2) The potassium humate fertilizer significantly decreased No. of days from sowing to the first flower appearance as well as, to the first opening boll, boll age and consequently, increased earliness percentage.

3) The treatment of potassium humate produced the highest values for No. of opened bolls/plant, boll weight and seed cotton yield/plant and consequently, the highest seed cotton yield/fed., while, the sources of potassium fertilizer did not exhibit any significant effect on No. of plants/fed., at harvest in both seasons.

4) The application times had significant effects on all growth attributes. The soil application with foliar application sprayed three times at squaring, start and peak of flowering stages, significantly, decreased days from sowing to the first flower appearance as well as, to the first opening boll and boll age, and increased earliness \% compared to the other potassium application treatments, and significantly increased No. of opened bolls/plant, boll weight, seed cotton yield/plant and consequently seed cotton yield/fed. in both seasons.
\end{abstract}

KEY WORDS: Cotton, Potassium sources, Potassein, Fertilization, Earliness, Growth, Yield, Calcareous soils.

\section{INTRODUCTION}

In Egypt, cotton is one of the most important crops for both local industry and export. Cotton fiber is the main raw material for the textile industry, which is the largest industry in Egypt. Both area and production are decreasing from one 
year to another. Two major decisions should be taken to restore the situation of the Egyptian cotton. The first is the improvement of the growing conditions of the crop or simply improving the crop management. The second is the reduction of production cost, especially cost of mineral fertilizers (Abou Zaid, 1999). Soil fertility and crop management are the two most important factors of modern agricultural activity (Sawan et al., 2006).

The soil under the present investigation was characterized by high calcium carbonate and low fertility status that could influence crop growth. Among the management practices, one factor is very essential, this is potassium (K) fertilizer. Recently, K deficiency in soil due to crop uptake, runoff, leaching and soil erosion (Sheng and Huang, 2002). Foliar potassium (K) application is one of the solution to improve the growing condition of the crop or simply improving the crop management, reduction of the environmental pollution and production cost (Abou-Zaid et al., 2009). This Nile silt was a source for K-bearing minerals that enriched the soil during the seasonal floods (Abd El-Hadi et al., 1997). Continuous crop removal without replenishment of these nutrients can lead to an irreparable damage to soil fertility (Sawan et al., 2006).

Potassium $(\mathrm{K})$ is an important nutrient that has favorable effects on the metabolism of nucleic acids, proteins, vitamins and growth substances. Furthermore, $\mathrm{K}$ plays an important role in the translocation of photsynthates from sources to sinks (Bednarz and Oosterhuis, 1999 and Morteza et al., 2005). Many studies have shown an increase in yield and quality in response to potassium fertilization as reported by (El-Haddad et al., 2001; El-Shazly et al., 2003; El-Masri et al., 2005; Hamed, 2006; Abou-Zaid et al., 2009; Beheary et al., 2012; Emara, 2012; Radwan et al., 2012; and Abou-Zaid et al., 2013). Moreover, several workers documented favorable responses of cotton growth, productivity to application of potassium as reported by, (Haroon et al., 2010; Emara and Hamoda, 2012 and Abou-Zaid et al. 2013). However, (Chellaiah et al., 2001; Basbag, 2008; Emara and Hamoda, 2012; Radwan et al., 2012 and Seadh et al., 2012) who indicated that application of potassium treatments significantly improved the No. of bolls/plant, boll weight and seed cotton yield.

Our objectives were to determine the influence of soil and foliar applied potassium fertilization for some sources of potassium and interaction between them on growth, earliness, yield and its components of Egyptian cotton Giza 86 cultivar in the newly reclaimed calcareous soil of Nubaria, Alexandria governorate.

\section{MATERIALS AND METHODS}

Two field experiments were conducted in Nubaria Agri. Res. Station, Alexandria governorate, Egypt during two growing seasons (2012 and 2013) to study the effect of some sources of potassium fertilizer, soil and foliar application times on growth, earliness, yield and its components of Egyptian long staple cotton cultivar Giza 86 (Gossypium barbadense, L.). The experimental design was a split plot design with four replications. The main plots involved the potassium sources with three treatments namely; $A$. Potassium sulphate, B. Potassium humate and C. Potassein. The Potassein product is produced by the General Organization for Agricultural Equalization Fund (GOAEF), Ministry of Agriculture, Egypt. The sub plots involved the five 
treatments of potassium application methods as: 1. soil application at thinning, 2. Soil application at thinning + foliar spraying two times (at initiation of flowering and two weeks after flowering), 3. soil application + foliar spraying three times (at squaring, initiation of flowering and two weeks after flowering), 4. Foliar spraying two times (at initiation of flowering and two weeks after flowering) and 5. Foliar spraying three times (at squaring, initiation of flowering and two weeks after flowering).Some soil properties were determined according to the method described by Page et al. (1982) and are presented in Table 1. In both seasons, the soil texture was sandy clay loam, low content of organic matter, very high calcium carbonate and non-saline. The available amounts of macro- elements were moderate for nitrogen, low for phosphorus and potassium. Regarding, available amounts of micro-nutrients, $\mathrm{Fe}, \mathrm{Cu}$ and $\mathrm{Mn}$ were of medium levels in the soil, while $\mathrm{Zn}$ and $\mathrm{B}$ were of low amounts (Table, 1 ).

Table (1). Some soil properties of the experimental sites at Nubaria in 2012 and 2013 seasons

\begin{tabular}{|c|c|c|c|c|c|c|c|c|c|c|c|c|}
\hline \multicolumn{13}{|c|}{ Mechanical analysis } \\
\hline Season & \multicolumn{2}{|c|}{ Clay (\%) } & & \multicolumn{2}{|c|}{ Sand (\%) } & \multicolumn{3}{|c|}{$\begin{array}{c}\text { Organic matter } \\
(\%)\end{array}$} & \multicolumn{4}{|c|}{ Texture class } \\
\hline 2012 & \multicolumn{2}{|c|}{23.35} & 21.17 & \multicolumn{2}{|c|}{52.20} & \multicolumn{3}{|c|}{0.78} & \multirow{2}{*}{\multicolumn{4}{|c|}{ Sandy clay loam }} \\
\hline 2013 & \multicolumn{2}{|c|}{22.63} & 23.61 & \multicolumn{2}{|c|}{53.38} & \multicolumn{3}{|c|}{0.81} & & & & \\
\hline \multicolumn{13}{|c|}{ Chemical analysis } \\
\hline \multirow{2}{*}{ Season } & \multirow{2}{*}{$\mathrm{pH}$} & \multirow{2}{*}{$\begin{array}{c}E C \\
(\mathrm{ds} / \mathrm{m})\end{array}$} & \multirow{2}{*}{$\begin{array}{c}\mathrm{HCO}_{3}^{-} \\
(\%)\end{array}$} & \multirow{2}{*}{$\begin{array}{c}\mathrm{Ca} \mathrm{CO}_{3} \\
(\%)\end{array}$} & \multicolumn{8}{|c|}{ Available element $(\mathrm{mg} / \mathrm{kg})$} \\
\hline & & & & & $\mathrm{N}$ & $P$ & $\mathrm{~K}$ & $\mathrm{Fe}$ & $B$ & $\mathrm{Zn}$ & $\mathrm{Cu}$ & $\mathrm{Mn}$ \\
\hline 2012 & 8.05 & 1.96 & 12.21 & 24.78 & 28.2 & 7.39 & 199.1 & 5.3 & 1.0 & 0.75 & 1.2 & 4.5 \\
\hline 2013 & 8.15 & 1.88 & 11.65 & 24.43 & 25.7 & 6.45 & 186.9 & 4.2 & 0.8 & 0.96 & 2.5 & 5.6 \\
\hline
\end{tabular}

The area of each plot was $16.25 \mathrm{~m}^{2}$ (including five ridges each of $0.65 \mathrm{~m}$ wide $x 5 \mathrm{~m}$ long). Distance between hills was $25 \mathrm{~cm}$. Cotton seeds of Egyptian long staple cotton cultivar Giza 86 (Gossypium Barbadense, L.) were sown on 17 and 22 April after two cuts of Egyptian clover Barseem (Trifolium alexandrinum, L.) in 2012 and 2013 seasons, respectively. Cotton plant was irrigated, during the whole growing season, eight times in addition to sowing irrigation. The first irrigation was applied after 21 days from sowing, while the other seven irrigations were given at 15-days interval. Before the second irrigation, the plants were thinned to two plants/hill. Hand hoeing was carried out three times during the season before the first, second and third irrigations, respectively.

Phosphorus in the form of superphosphate $\left(15.5 \% \quad \mathrm{P}_{2} \mathrm{O}_{5}\right)$ was applied during land preparation at the rate of $31 \mathrm{~kg} \mathrm{P}_{2} \mathrm{O}_{5} / \mathrm{fed}$. Average yearly nitrogen fertilizer rate for cotton was $75 \mathrm{Kg} \mathrm{N} / \mathrm{fed}$., in form of ammonium nitrate $(33.5 \%$ $\mathrm{N})$ was applied in two equal doses $(37.5+37.5 \mathrm{~kg} \mathrm{~N} / \mathrm{fed}$.), i.e., the first dose after thinning and before the second irrigation, the second dose before the third irrigation. Potassium fertilizer was added according to the experimental treatments (source, rate, method and date of application). Potassium sulphate $\left(48 \% \mathrm{~K}_{2} \mathrm{O}\right)$ was applied at the rate of 24 and $2.4 \mathrm{~kg} \mathrm{~K} \mathrm{~K}_{2} \mathrm{O} / \mathrm{fed}$., for the soil and foliar applications, respectively. Potassium humate fertilizer $(20 \%$ humic acid and $8 \% \mathrm{~K}_{2} \mathrm{O}$ ) was applied at the rate of 2 and $1 \mathrm{~L} / \mathrm{fed}$., for the soil and foliar 
applications, respectively. Potassein fertilizer $\left(30 \% \mathrm{~K}_{2} \mathrm{O}\right.$ and $\left.\mathrm{P}_{2} \mathrm{O}_{5} 10 \%\right)$ was applied at the rate of 2 and 1 L/fed., for the soil and foliar applications, respectively. The soil applications after thinning in the form of potassium source. The other standard agricultural practices were followed throughout the growing seasons. The first pick of seed cotton yield was performed by hand, on September 22, while the second pick was on October 9 for the first season. The respective dates of picking for the second season were September 28 and October 15.

In both seasons, five representative hills (10 plants/plot) were taken at random in order to study the following traits; A. Growth attributes: Plant height at harvest, No. of sympodia/plant and first sympodial position, B. Earliness parameter: Days from sowing to the first flower appearance, as well as to the first opening boll, boll age and earliness percentage and $\mathrm{C}$. Yield and its components: No. of opened bolls/plant, boll weight $(\mathrm{g})$, seed cotton yield/plant (g) and No. of plants/fed. The yield of seed cotton in kentars/fed. was estimated from the three inner ridge (One Kentar $=157.5 \mathrm{~kg}$ ).

The obtained data of the two seasons were subjected to statistical analysis according to Gomez and Gomez (1984), and L.S.D. values at 5\% level of significance were used for comparison between means.

\section{RESULTS AND DISCUSSION}

The results of growth attributes, earliness parameters, yield and its components as affected by potassium sources fertilizers, application times and interaction treatments on cotton Giza 86 during 2012 and 2013 seasons are shown in Tables (2 to 4).

\section{A. Growth attributes:}

\section{A.1. As affected by sources of potassium:}

The results in Table (2) indicated that the three sources potassium had significant effects on all growth attributes. The tallest plants (160.8 and 152.2 $\mathrm{cm}$ ), the highest of No. of sympodia/plant (15.64 and 13.82) and the lowest position of the first sympodium (6.16 and 6.54) were recorded using organic fertilizer "potassium humate" in the 2012 and 2013 seasons, respectively. Potassium humate activate some ion uptake along with stimulating the lateral roots at effective concentration of micronutrients.

\section{A.2. As affected by application times}

Results shown in Table (2) showed also significant differences among the application times on plant height at harvest, No. of sympodia/plant and first sympodial position in 2012 and 2013 seasons. The tallest plants (161.2 and $155.2 \mathrm{~cm}$ ) were produced from soil + foliar application three time, (at squaring, initiation of flowering and two weeks after flowering), while the shortest plants (149.8 and $146 \mathrm{~cm}$ ) were produced from foliar application two time, (at initiation of flowering and two weeks after flowering) in both seasons. The highest values of No. of sympodia/plant (16.06 and 14.21) were obtained from (Soil + foliar three times), while the lowest values (13.63 and 12.05) were obtained from (foliar two times), in 2012 and 2013 seasons, respectively. Hand broadcasting "soil application" at thinning when conjugated with foliar application sprayed three times significantly decreased the first sympodial position (6.12 and 6.22) in both seasons, respectively. These results were in agreement with (Sawan et 
al., 2006; Abou-Zaid et al., 2009; Beheary et al., 2012; Emara, 2012, and, Emara and Hamoda, 2012).

\section{A.3. As affected by interaction}

Regarding the interaction between potassium fertilizer sources $(A)$ and potassium application treatments (B), the data given in Table (2) showed that plant height, number of sympodia/plant and the first sympodial position in 2012 and 2013 seasons were significantly affected by the two-factor interactions.

Data presented in Table (2) showed that the combination treatment of soil potassium humate application ( $2 \mathrm{~L} / \mathrm{fed}$.) at thinning when conjugated with foliar sprayed $(1 \mathrm{~L} / \mathrm{fed}$.) three times (at squaring, initiation of flowering and two weeks after flowering) recorded the highest mean values of plant height (165.7 and $158.5 \mathrm{~cm}$ ), number of sympodia/plant (16.38 and 14.98 sympodia/plant) and the lowest first sympodial position (5.85 and 6.05 node) in 2012 and 2013 seasons, respectively.

\section{B. Earliness parameters:}

\section{B.1. As affected by sources of potassium:}

Data in Table (3) showed that all the earliness parameters; No. of days from sowing to the first flower appearance as well as, to the first opening boll, boll age and earliness \% were significantly affected by the three sources of potassium in 2012 and 2013 seasons. As for potassium sources "potassium humate" fertilizer significantly decreased No. of days from sowing to the first flower appearance (76.4 and 78.1 days) as well as, to the first opening boll (122.5 and 125.8 days), boll age (46.0 and 47.7 days) and consequently, increased earliness \% (69.8 and 64.7\%) in 2012 and 2013 seasons, respectively. These results may be due to the reducing position of the first sympodium of both flowering and boll setting. The primitive effect of potassium humate fertilizer on ealiness percentage may be due to that the useful role of organic matter which creates sutable conditions for plant growth such as decreasing EC and increasing soil nutrients (Beheary et al., 2012).Also, similar results were obtained by Emara and Hamoda, 2012)

\section{B.2. As affected by application times:}

Table (3) showed also significant differences among the application times on all the earliness parameters in 2012 and 2013 seasons. The soil application which foliar application sprayed three times (at squaring, initiation of flowering and two weeks after flowering), significantly decreased days from sowing to the first flower appearance (76.7 and 76.9 days) as well as, to the first opening boll (123.2 and 124.1 days) and boll age (46.4 and 47.1 days) and increased earliness \% $(69.2 \%$ and $66.0 \%)$ in both seasons, respectively, compared to the other potassium application treatments.

\section{B.3. As affected by interaction:}

There were a significantly interaction effects were found between two factors under study for the earliness parameters in Table (3).

Generally, data presented in Table (3) indicated that by using potassium humates with soil application and foliar 2 or 3 times tended to recorded the shortest period from sowing data to the first flower appearance as well as to the first opening boll and boll age, which led to the earliest maturity for this treatment as compared to the other treatments in the two seasons. 


\section{Yield and its components:}

\section{C.1. As affected by sources of potassium:}

The results in Table (4) showed that the No. of opened bolls/plant, boll weight, seed cotton yield/plant and seed cotton yield/fed were significantly affected by the sources of potassium fertilizer, except the number of plants per feddan in the two seasons (2012 and 2013). The potassium humate fertilizer recorded the highest mean values for No. of opened bolls/plant (14.3 and 14.0 bolls/plant), boll weight (2.56 and $2.45 \mathrm{~g}$ ) and seed cotton yield/plant (36.56 and $34.25 \mathrm{~g})$ and consequently obtained the highest seed cotton yield/fed. (7.39 and 6.69) in both seasons 2012 and 2013, respectively. It could be concluded that the seed cotton yield responded with using higher potassium humate level is attributed to increasing nitrogen nutrition as influenced by increasing nitrogen concentration in plant tissues (Radwan et al., 2012). Also, Emara and Hamoda (2012) concluded that humic acid application significantly increased seed cotton yield /fed.

\section{C.2. As affected by application times:}

Respecting data in the same table it could be noticed that there were significantly effect on the No. of opened bolls/plant, boll weight, seed cotton yield/plant and seed cotton yield/fed., due to the potassium application timing in both seasons. The soil application which foliar application sprayed three times (at squaring, initiation of flowering and two weeks after flowering) recorded a significant increase in No. of opened bolls/plant $(14.3,14.1)$, boll weight $(2.55$, $2.52 \mathrm{~g}$ ), seed cotton yield/plant $(36.52,35.13 \mathrm{~g})$ and consequently increased the seed cotton yield/fed. (7.37, 7.22 kentar/fed) in both 2012 and 2013 seasons, respectively. The increase in yield and its components due to soil application which foliar application sprayed at three times treatment, compared to the other studied treatments, may be attributed to the earliness parameters i.e., the decrease in days from sowing to the first flower appearance as well as, to the first opening boll and boll age, Table (3).

\section{C.3. As affected by interaction:}

Insignificant interaction between sources of potassium (A) and application times (B) in all yield and its components characters, except the number of opening bolls per plant and seed cotton yield per feddan in 2013 season only, Table (4). The highest mean values (38.95 and $35.60 \mathrm{~g} / \mathrm{plant}, 8.16$ and 7.10 kentar/fed.) in the first and second seasons, respectively, were attained when used potassium humates with soil+ foliar 3 times. The increase in seed cotton yield for this treatment interaction was due to the significance decrease in all the earliness parameters and the increase in plant height at harvest, No. of sympodia/plant, No. of opened bolls/plant and seed cotton yield/plant. These results are in accordance with those outlined by Abou-Zaid et al. (2009), Beheary et al. (2012), Emara and Hamoda (2012) and Abou-Zaid et al. (2013).

\section{CONCLUSION}

The results obtained in this study could lead us to a package of recommendations, which seemed to be useful for increasing the cotton yield production in quantity. It could be concluded that in addition of potassium humate soil application with foliar application sprayed three times (at squaring, initiation of flowering and two weeks after flowering) for obtaining high 
productivity of cotton (Giza 86 cultivar), under Nubaria Agricultural Research Station, Alexandria governorate.

Table (2). Growth attributes as affected by potassium sources, application times and interaction during 2012 and 2013 seasons.

\begin{tabular}{|c|c|c|c|c|c|c|c|}
\hline \multicolumn{2}{|c|}{ Characters } & \multicolumn{2}{|c|}{$\begin{array}{l}\text { Plant height at } \\
\text { harvest }(\mathrm{cm})\end{array}$} & \multicolumn{2}{|c|}{$\begin{array}{c}\text { No. of } \\
\text { sympodia/plant }\end{array}$} & \multicolumn{2}{|c|}{$\begin{array}{c}\text { First sympodial } \\
\text { position } \\
\text { (Node) } \\
\end{array}$} \\
\hline Treatments & Seasons & 2012 & 2013 & 2012 & 2013 & 2012 & 2013 \\
\hline \multirow{3}{*}{ Potassium sources $(A)$} & $\begin{array}{l}\text { Potassium } \\
\text { sulphates }\end{array}$ & 150.5 & 148.5 & 14.14 & 12.62 & 7.07 & 7.07 \\
\hline & Potassium humates & 160.8 & 152.2 & 15.64 & 13.82 & 6.16 & 6.54 \\
\hline & Potassien & 154.3 & 149.7 & 14.78 & 12.10 & 6.63 & 6.81 \\
\hline \multirow{3}{*}{ LSD at 0.05 for $(A)$} & & 1.14 & 0.68 & 0.30 & 0.12 & 0.16 & 0.11 \\
\hline & Soil & 155.0 & 149.5 & 14.53 & 13.13 & 6.64 & 6.90 \\
\hline & Soil + foliar 2 times & 157.0 & 152.0 & 15.25 & 13.69 & 6.33 & 6.54 \\
\hline \multirow[t]{3}{*}{ Potassium application (B) } & Soil + foliar 3 times & 161.2 & 155.5 & 16.06 & 14.21 & 6.12 & 6.22 \\
\hline & Foliar 2 times & 149.8 & 146.0 & 13.63 & 12.05 & 7.28 & 7.28 \\
\hline & Foliar 3 times & 153.4 & 147.0 & 14.79 & 12.65 & 6.72 & 7.08 \\
\hline LSD at 0.05 for $(B)$ & & 1.19 & 0.83 & 0.19 & 0.15 & 0.13 & 0.14 \\
\hline \multicolumn{8}{|l|}{ Interaction (AB) } \\
\hline \multirow{5}{*}{ Potassium sulphates } & Soil & 147.7 & 148.5 & 13.78 & 12.58 & 7.20 & 7.13 \\
\hline & Soil + foliar 2 times & 153.2 & 149.5 & 14.05 & 13.10 & 6.75 & 6.88 \\
\hline & Soil + foliar 3 times & 157.5 & 152.5 & 15.65 & 13.73 & 6.55 & 6.43 \\
\hline & Foliar 2 times & 145.7 & 145.7 & 13.15 & 11.78 & 7.68 & 7.53 \\
\hline & Foliar 3 times & 148.5 & 146.5 & 14.05 & 11.93 & 7.18 & 7.38 \\
\hline \multirow{5}{*}{ Potassium humates } & Soil & 160.7 & 151.0 & 15.68 & 13.83 & 6.05 & 6.63 \\
\hline & Soil + foliar 2 times & 161.5 & 154.5 & 16.08 & 14.23 & 5.88 & 6.10 \\
\hline & Soil + foliar 3 times & 165.7 & 158.5 & 16.38 & 14.98 & 5.85 & 6.05 \\
\hline & Foliar 2 times & 155.7 & 147.7 & 14.13 & 12.55 & 6.73 & 7.20 \\
\hline & Foliar 3 times & 160.5 & 149.5 & 15.95 & 13.53 & 6.28 & 6.73 \\
\hline \multirow{5}{*}{ Potassien } & Soil & 156.5 & 149.0 & 14.13 & 12.98 & 6.68 & 6.93 \\
\hline & Soil + foliar 2 times & 156.2 & 152.2 & 15.63 & 13.75 & 6.35 & 6.65 \\
\hline & Soil + foliar 3 times & 160.5 & 155.5 & 16.15 & 13.93 & 5.95 & 6.18 \\
\hline & Foliar 2 times & 147.2 & 144.5 & 13.63 & 11.83 & 7.45 & 7.13 \\
\hline & Foliar 3 times & 151.2 & 147.5 & 14.38 & 12.50 & 6.70 & 7.15 \\
\hline LSD at 0.05 for $(A \times B)$ & & 2.07 & 1.44 & 0.34 & 0.27 & 0.24 & 0.25 \\
\hline
\end{tabular}

Table (3). Earliness parameters as affected by potassium sources, application times and interaction during 2012 and 2013 seasons

\begin{tabular}{|c|c|c|c|c|c|c|c|c|c|}
\hline \multicolumn{2}{|c|}{ Characters } & \multicolumn{2}{|c|}{$\begin{array}{l}\text { Days to the } \\
\text { first flower } \\
\text { appearance }\end{array}$} & \multicolumn{2}{|c|}{$\begin{array}{l}\text { Days to the } \\
\text { first opening } \\
\text { boll }\end{array}$} & \multicolumn{2}{|c|}{$\begin{array}{l}\text { Boll age } \\
\text { (Days) }\end{array}$} & \multicolumn{2}{|c|}{$\begin{array}{c}\text { Earliness } \\
\text { percentage (\%) }\end{array}$} \\
\hline \multicolumn{2}{|l|}{ Treatments } & 2012 & 2013 & 2012 & 2013 & 2012 & 2013 & 2012 & 2013 \\
\hline \multirow{3}{*}{$\begin{array}{l}\text { Potassium } \\
\text { sources (A) }\end{array}$} & $\begin{array}{l}\text { Potassium } \\
\text { sulphates }\end{array}$ & 81.3 & 81.1 & 132.3 & 132.8 & 51.0 & 51.7 & 59.9 & 60.3 \\
\hline & $\begin{array}{l}\text { Potassium } \\
\text { humates }\end{array}$ & 76.4 & 78.1 & 122.5 & 125.8 & 46.0 & 47.7 & 69.8 & 64.7 \\
\hline & Potassien & 79.0 & 80.3 & 127.7 & 129.9 & 48.7 & 49.6 & 64.7 & 62.7 \\
\hline \multicolumn{2}{|l|}{ LSD at 0.05 for $(A)$} & 0.78 & 0.34 & 1.19 & 0.79 & 0.51 & 0.52 & 1.18 & 1.87 \\
\hline \multirow{5}{*}{$\begin{array}{l}\text { Potassium } \\
\text { application (B) }\end{array}$} & Soil & 78.9 & 79.8 & 127.5 & 129.2 & 48.6 & 49.4 & 64.2 & 62.6 \\
\hline & Soil + foliar 2 times & 77.2 & 78.1 & 124.4 & 126.3 & 47.2 & 48.2 & 67.3 & 65.4 \\
\hline & Soil + foliar 3 times & 76.7 & 76.9 & 123.2 & 124.1 & 46.4 & 47.1 & 69.2 & 66.0 \\
\hline & Foliar 2 times & 82.6 & 83.3 & 135.0 & 136.2 & 52.3 & 52.8 & 58.3 & 57.8 \\
\hline & Foliar 3 times & 79.1 & 80.9 & 127.4 & 131.8 & 48.3 & 50.8 & 65.1 & 60.9 \\
\hline LSD at 0.05 for $(B)$ & & 0.66 & 0.43 & 1.11 & 0.58 & 0.60 & 0.34 & 1.04 & 2.11 \\
\hline \multicolumn{10}{|l|}{ Interactions $(\mathrm{AB})$} \\
\hline \multirow{4}{*}{$\begin{array}{l}\text { Potassium } \\
\text { sulphates }\end{array}$} & Soil & 82.1 & 81.7 & 133.1 & 132.3 & 51.0 & 50.5 & 59.1 & 59.6 \\
\hline & Soil + foliar 2 times & 79.1 & 79.4 & 128.1 & 128.8 & 48.9 & 49.4 & 62.9 & 62.4 \\
\hline & Soil + foliar 3 times & 78.2 & 78.3 & 126.4 & 127.4 & 48.2 & 49.1 & 65.2 & 65.1 \\
\hline & Foliar 2 times & 85.2 & 85.0 & 140.8 & 141.9 & 55.6 & 56.8 & 52.9 & 55.5 \\
\hline
\end{tabular}




\begin{tabular}{|c|c|c|c|c|c|c|c|c|c|}
\hline \multirow{6}{*}{$\begin{array}{l}\text { Potassium } \\
\text { humates }\end{array}$} & Foliar 3 times & 81.8 & 81.0 & 133.0 & 133.8 & 51.2 & 52.7 & 59.5 & 59.0 \\
\hline & Soil & 76.1 & 78.3 & 122.4 & 126.8 & 46.3 & 48.5 & 68.8 & 65.3 \\
\hline & Soil + foliar 2 times & 75.2 & 76.3 & 120.2 & 123.3 & 45.0 & 47.0 & 72.2 & 68.6 \\
\hline & Soil + foliar 3 times & 75.8 & 75.6 & 120.6 & 121.3 & 44.8 & 45.6 & 73.4 & 64.8 \\
\hline & Foliar 2 times & 78.8 & 81.2 & 127.9 & 130.8 & 49.0 & 49.5 & 63.9 & 60.1 \\
\hline & Foliar 3 times & 76.3 & 78.7 & 121.5 & 126.7 & 45.2 & 47.9 & 70.7 & 64.6 \\
\hline \multirow{5}{*}{ Potassien } & Soil & 78.6 & 79.3 & 127.1 & 128.6 & 48.5 & 49.3 & 64.6 & 63.1 \\
\hline & Soil + foliar 2 times & 77.4 & 78.6 & 124.9 & 126.6 & 47.6 & 48.2 & 66.8 & 65.2 \\
\hline & Soil + foliar 3 times & 76.1 & 76.7 & 122.4 & 123.4 & 46.3 & $46 . .6$ & 69.1 & 68.2 \\
\hline & Foliar 2 times & 83.8 & 83.8 & 136.2 & 135.8 & 52.4 & 52.1 & 58.1 & 57.9 \\
\hline & Foliar 3 times & 79.1 & 83.1 & 127.9 & 135.0 & 48.7 & 51.9 & 65.0 & 59.1 \\
\hline \multicolumn{2}{|c|}{ LSD at 0.05 for $(A \times B)$} & 1.15 & 0.76 & 1.93 & 1.01 & 1.05 & 0.60 & N.S & N.S \\
\hline
\end{tabular}

Table (4). Yield and its components as affected by potassium sources, application times and interaction during 2012 and 2013 seasons

\begin{tabular}{|c|c|c|c|c|c|c|c|c|c|c|c|}
\hline \multicolumn{2}{|r|}{ Characters } & \multicolumn{2}{|c|}{$\begin{array}{c}\text { No. of } \\
\text { opened } \\
\text { bolls/plant }\end{array}$} & \multicolumn{2}{|c|}{$\begin{array}{l}\text { Boll weight } \\
(\mathrm{g})\end{array}$} & \multicolumn{2}{|c|}{$\begin{array}{l}\text { Seed cotton } \\
\text { yield/plant (g) }\end{array}$} & \multicolumn{2}{|c|}{$\begin{array}{c}\text { No. of } \\
\text { plants/fed. }\end{array}$} & \multicolumn{2}{|c|}{$\begin{array}{c}\text { Seed cotton } \\
\text { yield } \\
\text { (Kentar/fed.) }\end{array}$} \\
\hline \multicolumn{2}{|c|}{ Treatments } & 2012 & 2013 & 2012 & 2013 & 2012 & 2013 & 2012 & 2013 & 2012 & 2013 \\
\hline $\begin{array}{l}\text { Potassium } \\
\text { sources (A) }\end{array}$ & $\begin{array}{l}\text { Potassium sulphates } \\
\text { Potassium humates } \\
\text { Potassien } \\
\text { (A) }\end{array}$ & $\begin{array}{c}13.3 \\
14.3 \\
13.6 \\
0.16 \\
\end{array}$ & $\begin{array}{l}13.5 \\
14.0 \\
13.5 \\
0.06 \\
\end{array}$ & $\begin{array}{l}2.42 \\
2.56 \\
2.48 \\
0.03 \\
\end{array}$ & $\begin{array}{l}2.37 \\
2.45 \\
2.40 \\
0.01 \\
\end{array}$ & $\begin{array}{c}32.18 \\
36.56 \\
33.83 \\
0.60 \\
\end{array}$ & $\begin{array}{c}32.14 \\
34.25 \\
32.72 \\
0.59 \\
\end{array}$ & $\begin{array}{c}49645 \\
49548 \\
49483 \\
\text { N.S. }\end{array}$ & $\begin{array}{c}48337 \\
48433 \\
48321 \\
\text { N.S. }\end{array}$ & $\begin{array}{l}6.05 \\
7.39 \\
6.54 \\
0.15 \\
\end{array}$ & $\begin{array}{l}5.84 \\
6.69 \\
6.03 \\
0.08 \\
\end{array}$ \\
\hline $\begin{array}{l}\text { Potassium } \\
\text { application } \\
\text { (B) }\end{array}$ & $\begin{array}{l}\text { Soil } \\
\text { Soil + foliar } 2 \text { times } \\
\text { Soil + foliar } 3 \text { times } \\
\text { Foliar } 2 \text { times } \\
\text { Foliar } 3 \text { times } \\
\text { (B) }\end{array}$ & $\begin{array}{l}13.7 \\
13.8 \\
14.3 \\
13.2 \\
13.5 \\
0.15 \\
\end{array}$ & $\begin{array}{l}13.7 \\
13.8 \\
14.1 \\
13.2 \\
13.7 \\
0.17 \\
\end{array}$ & $\begin{array}{l}2.48 \\
2.52 \\
2.55 \\
2.39 \\
2.50 \\
0.041\end{array}$ & $\begin{array}{l}2.41 \\
2.46 \\
2.52 \\
2.31 \\
2.34 \\
0.028 \\
\end{array}$ & $\begin{array}{c}34.07 \\
35.03 \\
36.52 \\
31.55 \\
33.78 \\
0.48 \\
\end{array}$ & $\begin{array}{c}33.07 \\
34.06 \\
35.13 \\
30.66 \\
32.28 \\
0.56 \\
\end{array}$ & $\begin{array}{c}49580 \\
49581 \\
49607 \\
49607 \\
49419 \\
\text { N.S. }\end{array}$ & $\begin{array}{l}48235 \\
48423 \\
48396 \\
48423 \\
48342 \\
\text { N.S. } \\
\end{array}$ & $\begin{array}{l}6.63 \\
6.94 \\
7.37 \\
5.86 \\
6.50 \\
0.17 \\
\end{array}$ & $\begin{array}{l}6.07 \\
6.39 \\
7.22 \\
5.31 \\
5.94 \\
0.07\end{array}$ \\
\hline \multicolumn{12}{|c|}{ Interaction $(\mathrm{AB})$} \\
\hline \multirow[t]{2}{*}{$\begin{array}{l}\text { Potassium } \\
\text { sulphates }\end{array}$} & $\begin{array}{l}\text { Soil } \\
\text { Soil + foliar } 2 \text { times } \\
\text { Soil + foliar } 3 \text { times } \\
\text { Foliar } 2 \text { times }\end{array}$ & $\begin{array}{l}13.3 \\
13.5 \\
13.9 \\
12.7\end{array}$ & $\begin{array}{l}13.5 \\
13.6 \\
13 . .9 \\
12.8\end{array}$ & $\begin{array}{l}2.40 \\
2.45 \\
2.48 \\
2.34\end{array}$ & $\begin{array}{l}2.38 \\
2.41 \\
2.48 \\
2.29\end{array}$ & $\begin{array}{l}32.05 \\
33.05 \\
r \leqslant . \leqslant v \\
29.71\end{array}$ & $\begin{array}{l}32.13 \\
32.78 \\
34.4 \vee \\
29.30\end{array}$ & $\begin{array}{l}49499 \\
49742 \\
49742 \\
49742\end{array}$ & $\begin{array}{l}48207 \\
48288 \\
48530 \\
48530\end{array}$ & $\begin{array}{l}5.97 \\
6.34 \\
6.72 \\
5.31\end{array}$ & $\begin{array}{l}5.73 \\
5.95 \\
6.72 \\
4.93\end{array}$ \\
\hline & $\begin{array}{l}\text { Foliar } 3 \text { times } \\
\text { Soil }\end{array}$ & $\begin{array}{l}13.1 \\
14.3\end{array}$ & $\begin{array}{l}13.9 \\
14.0\end{array}$ & $\begin{array}{l}2.43 \\
2.55\end{array}$ & $\begin{array}{l}2.30 \\
2.45\end{array}$ & $\begin{array}{l}31.79 \\
36.44\end{array}$ & $\begin{array}{l}32.05 \\
34.43\end{array}$ & $\begin{array}{l}49499 \\
49580\end{array}$ & $\begin{array}{l}48127 \\
48288\end{array}$ & $\begin{array}{l}5.91 \\
7.37\end{array}$ & $\begin{array}{l}5.89 \\
6.51\end{array}$ \\
\hline \multirow{4}{*}{$\begin{array}{l}\text { Potassium } \\
\text { humates }\end{array}$} & Soil + foliar 2 times & 14.4 & 14.2 & 2.59 & 2.51 & 37.40 & 35.50 & 49580 & 48207 & 7.69 & 6.81 \\
\hline & $\begin{array}{l}\text { Soil + foliar } 3 \text { times } \\
\text { Foliar } 2 \text { times }\end{array}$ & $\begin{array}{l}14.9 \\
13.7\end{array}$ & $\begin{array}{l}14.3 \\
13.8\end{array}$ & $\begin{array}{l}2.61 \\
2.47\end{array}$ & $\begin{array}{l}2.57 \\
234\end{array}$ & $\begin{array}{l}38.95 \\
33.83\end{array}$ & $\begin{array}{l}35.60 \\
32.31\end{array}$ & $\begin{array}{l}49499 \\
49419\end{array}$ & $\begin{array}{l}48773 \\
48369\end{array}$ & $\begin{array}{l}8.16 \\
6.52\end{array}$ & $\begin{array}{l}7.10 \\
5.84\end{array}$ \\
\hline & Foliar 3 times & 14.0 & 13.9 & 2.57 & 2.40 & 36.17 & 33.43 & 49338 & 48127 & 7.21 & 6.29 \\
\hline & Soil & 13.6 & 13.6 & 2.48 & 2.40 & 33.73 & 32.65 & 49661 & 48450 & 6.56 & 5.97 \\
\hline \multirow{4}{*}{ Potassien } & Soil tr - r t & 13.7 & 13.7 & 2.5 & 2.4 & 34.65 & 33.82 & 49419 & 48207 & 6.78 & 6.41 \\
\hline & Soil + foliar 3 times & 14.1 & 14.1 & 2.55 & 2.51 & 36.14 & 35.41 & 49580 & 48773 & 7.24 & 6.95 \\
\hline & Foliar 2 times & 13.2 & 13.1 & 2.36 & 2.31 & 31.26 & 30.36 & 49661 & 48127 & 5.75 & 5.15 \\
\hline & Foliar 3 times & 13.3 & 13.3 & 2.5 & 2.3 & 33.39 & 31.37 & 49419 & 47965 & 6.39 & 5.65 \\
\hline \multicolumn{2}{|c|}{ LSD at 0.05 for $(A \times B)$} & N.S & 0.29 & N.S & N.S & N.S & N.S & N.S & N.S & N.S & 0.13 \\
\hline
\end{tabular}

\section{REFERENCES}

Abd El-Hadi, A.H., M.S Khadr and M.H. Taha (1997). Cotton fertilization under the intensive cropping system in Egyptian agriculture. Proc. IRCRNC Joint Meeting of the Working Groups on Cotton (Nutrition and Growth Regulators), Cairo, Egypt, pp. $147-154$.

Abou-Zaid, M.K. (1999). Optimum technology for Egyptian cotton production in the newly reclaimed desert land of Egypt. Cotton Bull. Jan., 1999: 2743, International Commerce Co., Ministry of Commerce, Egypt.

Abou-Zaid, M.K., M.A. Emara and S.A. Hamoda (2009). Future of Egyptian cotton production in the newly reclaimed desert land of Egypt: 10Cotton response to soil, foliar potassium application and potassium dissolving bacteria (KDB). J. Adv. Agric. Res., (Fac. Agric. Saba Basha), 42(1): 73 - 80. 
Abou-Zaid, M.K., M.A. Emara and S.A. Hamoda (2013). Effect of humex and bio-fertilization on growth, yield and quality of cotton under calcareous soil conditions. The $2^{\text {nd }}$ Alexandria International Cotton Conference, Faculty of Agric., Saba Basha, Alexandria, Univ., Alex. 10 - 11 April, 2013, Vol. (1): 12 - 21.

Basbag, S. (2008). Effects of humic acid application on yield and quality of cotton. Asian J. of Chemistry. 20(3): 1961 - 1966.

Bednarz, C.W and D.M. Oosterhuis (1999). Physiological changes assiociated with potassium deficiency in cotton. J. Plant Nutr., 22: $303-313$.

Beheary, M.G., M.K. Abou-Zaid, I. A. Ibrahim and Hend M. Abou-Zaid (2012). Effect of humic acid and nitrogen fertilization under different irigation intervals on yield and fibre properties of Egyptian cotton. Alexandria International Cotton Conference, Fac. of Agric., Saba Basha Alexandria, Univ., Alexandria. $17-18^{\text {th }}$ April, 2012, Vol. (1): $87-102$.

Chellaiah, N.; U. Solaiappan and S. Senthivel (2001). Studies on foliar nutrition on productivity of summer irrigated cotton. Madras Agric. J., 88(1/3): $180-181$.

El-Haddad, E.H., M.K. Abou-Zaid and S.Sh. El-Tabbakh (2001). Future of Egyptian cotton production in the new reclaimed desert land of Egypt: 5- Response of cotton to fertilization in calcareous soils of the Northwest Coast of Egypt. Minufiya, J. Agric. Res., 26(6): 1533 - 1545.

El-Masri, M.F., W.M. El-Shazly and K.A. Ziadah (2005). Respones of Giza 88 cotton cultivar to foliar spraying with boron, potassium or a bioregulator SGA-1. J. Agric. Sci. Mansoura Univ., 30 (10): 5739 - 5755.

El-Shazly, W.M., R.M. Khalifa and O.A. Nofal (2003). Respones of cotton Giza 89 cultivar to foliar spray with boron, potassium or a bioregulator SGA-1. Egypt. J. Appl. Sci., 18(4B): 676 - 699.

Emara, M.A. 2012. Response of cotton growth and productivity to application of potassium and zinc under normal and late sowing dates. J. Plant Production, Mansoura Univ., Vol. 3 (3): 509 - 514.

Emara, M.A. and S.F. Hamoda (2012). Effect of humex on growth, yield and quality of cotton under calcareous soil conditions. Alexandria International Cotton Conference, Faculty of Agric., Saba Basha Alexandria, Univ., Alexandria. $17-18^{\text {th }}$ April, 2012, Vol. (1): $29-37$.

Gomez, K.A. and A.A. Gomez (ed.) (1984). "Statistical procedures for agricultural research". $2^{\text {ed }}$, John Wiley \& Sons, Inc., New York, USA.

Hamed, F.S. (2006). Response of cotton cultivar Giza 90 to nitrogen and potassium levels. Minia J. of Agric. Res. \& Develop., 26(2): 253 - 264.

Haroon, A., R. Khattak and D. Muhammad (2010). Seed cotton yield and nutrient concentrations as influenced by lignitic coal derived humic acid in salt affected soils. Sarhad J. of Agric., 26(1): 43 - 49.

Morteza, M., A. Slaton, M. Fred and C. Kennedy (2005). Effect of potassium fertilization on cotton yield and petiole. Summaries of Arkansas Cotton Res., pp: 74 - 78.

Page, A.L., R.H. Miller and D.R. Keeney. (ed.) (1982). "Methods of soil analysis". Part 2: Chemical and microbiological properties. Amer. Soc. Agron., Madison, Wisconsin.

Radwan, F.I., M.A. Gomaa; M.K. Abou-Zaid and Doaa, A. Awad (2012). Future of Egyptian cotton production in the newly reclaimed desert land 
of Egypt: 11-Response of Egyptian cotton to organic- mineral and biofertilization. J. Adv. Agric. Res., 17(3): 580 - 603.

Sawan, Z.M., M.H. Mahmoud and Amal H. El-Guibali (2006). Response of yield, yield components, and fiber properties of Egyptian cotton (Gossypium barbadense, L.) to nitrogen fertilization and foliar applied potassium and mepiquat chloride. J. of Cotton Sci., 10: $224-234$.

Seadh, S.E., H.A. Abd El-Aal and Shaimaa, O. El-Sayed (2012). Effect of NPK rates and humic acid applications on growth of Egyptian cotton. J. Plant Production, Mansoura Univ., 3(8): 2287 - 2299.

Sheng, X.F. and W.Y. Huang (2002). The conditions of releasing potassium by a silicate dissolving bacterial strain. NBT, Agric. Sci. China. 1: 662-666.

$$
\text { الملخص العربي }
$$

\section{أستجابة القطن المصري للإضافة الارضية والرش بالبوتاسيوم تحث ظروف الأراضي الجيرية}

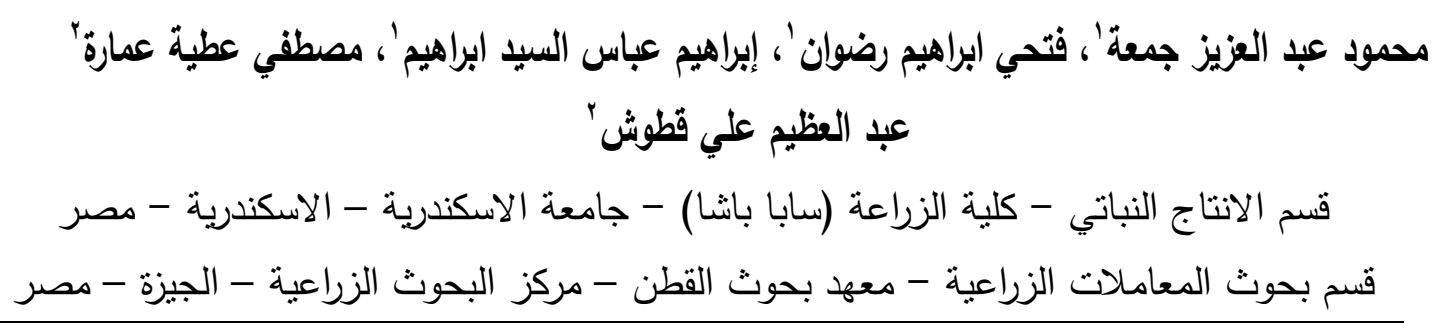

أجريت تجربتان حقليتان بمحطة البحوث الزراعية بالنوبارية - في أرض جيرية - خلال موسمي النمو

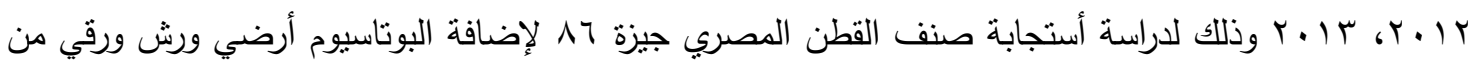
مصادر مختلفة وذلك تحت ظروف الاراضي الجيرية وأثر ذلك علي النمو، التبكير ، المحصول ومكوناته. زُرعت التجارب في تصميم القطع المنشقة مرة واحدة في أربعة مكررات حيث وضعت مصادر البوتاسيوم (1- سلفات

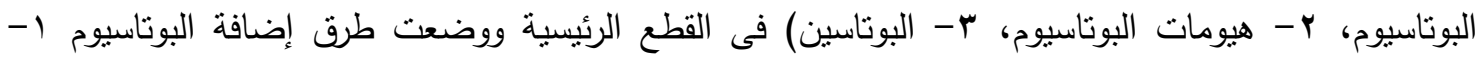

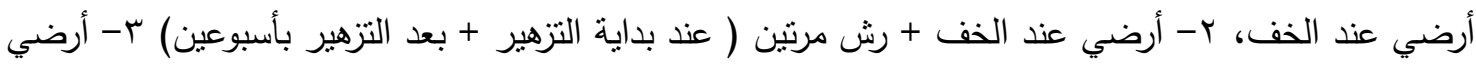

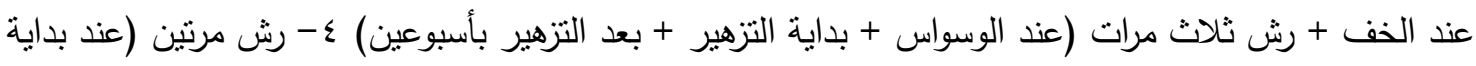
التزهير + بعد التزهير بأسبوعين) ه- رش ثلاث مرات (عند الوسواس + بداية التزهير + بعد التزهير بأسبوعين) فى القطع المنشقة.

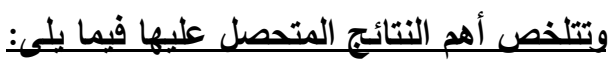

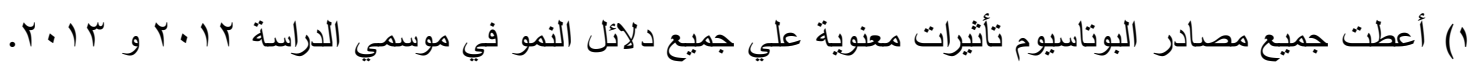

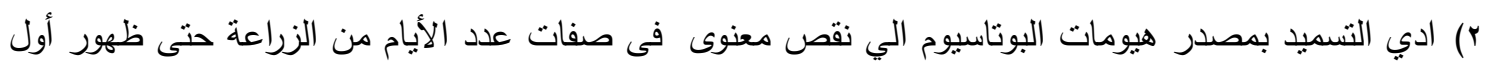

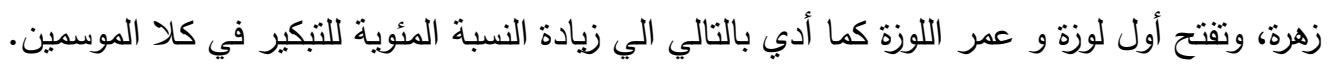

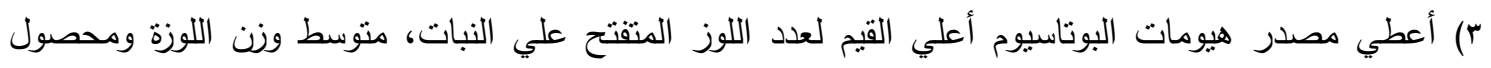

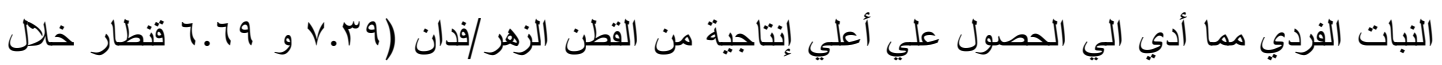




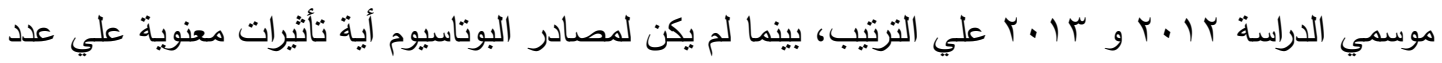
النباتات بالفدان عند الحصاد.

؛) أعطت مواعيد إضافة البوتاسيوم تأثيرات معنوية علي الصفات تحت الدراسة في موسمي النمو، معاملة الإضافة الارضية عند الخف + الرش ثلاث مرات أدت الي أنخفاضاً معنوياً لصفات عدد الأيام من الزراعة

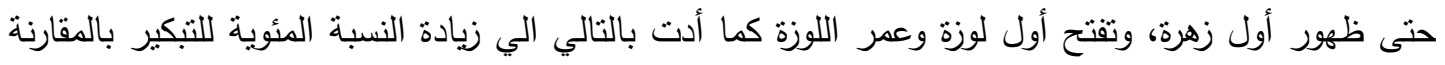

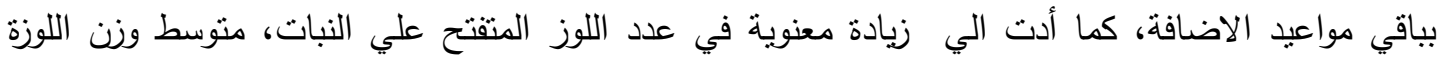

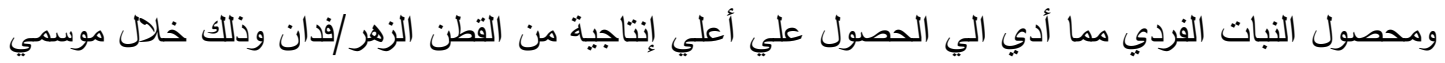

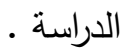

من النتائج المتحصل عليها والموضحة في هذه الدراسة فأنه يمكنا أعطاء التوصية بإضافة هيومات البوتاسيوم (إضافة أرضية عند الخف بمعدل r لتر/فدان + الرش بمعدل ا لتر/فدان ثلاث مرات (عند

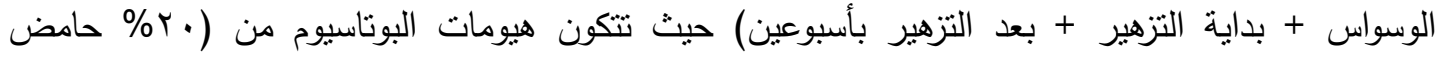

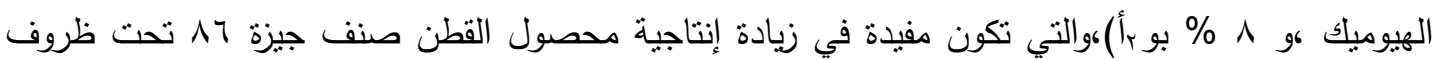

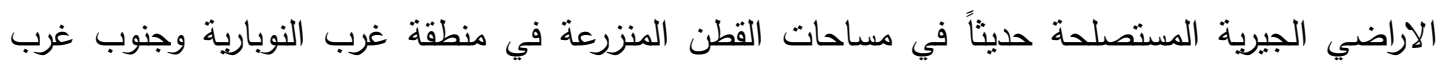

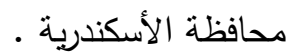

